\title{
人造大理石の黄変と発生要因
}

\section{YELLOWING OF THE RECONSTITUTED STONE AND THE OUTBREAK FACTORS}

\author{
高橋晃一郎—— $* 1$ 小川晴果 — $* 2$ \\ キーワード : \\ 人造大理石, 黄変, 発色団, 助色団, フーリエ変換赤外分光光度計
}

Keywords:

Reconstituted stone, Yellowing, Chromophore, Auxochrome, Fourier transform infrared spectrophotometer

1. はじめに

人造大理石にはテラゾーなど無機を主成分とするものと，日本で は主にキッチンの天板などに多用されている有機系人造大理石（以 下，人造大理石）があり，後者は種類が多く，意匠性も優れており 強度が高いことから海外の建築では，床材や壁材として広く使用さ れている。

しかしながら，人造大理石には不飽和ポリエステルやアクリルな どの樹脂やメーカー独自の様々な配合による添加剤などが使用され ており，これらが極微量含まれているだけでも，紫外線や熱，水， 酸素などの様々な外的要因による劣化が起きやすく, 天然石に比心゙ そのメカニズムも非常に複雑である ${ }^{1 ）}{ }^{2)}$ 。なかでも黄変は有機系材 料では最も多く発生しやすい劣化現象の一つである。海外の高温多 湿な環境下にて，床に敷設された人造大理石上の養生材を撤去した 直後から黄変する現象が発生し，その原因究明と最適な変色除去方 法の確立が必要となった。そこで, 本報では実際に使用された人造 大理石を用い, 各種劣化要因による黄変の再現, 化学分析による黄 変原因の特定，さらに過酸化水素水や表面研磨による黄変除去の可 能性と黄変の再発について検証した結果について述べる。

\section{2. 人造大理石の概要}

\section{1 人造大理石の種類と特徵}

人造大理石は使用されている樹脂の種類により, 次の 3 種類に大 別される。

・不飽和ポリエステル系人造大理石

・ビニルエステル系人造大理石

・アクリル系人造大理石

一般に，不飽和ポリエステル系人造大理石とビニルエステル系人 造大理石は強度が高く，耐薬品性や耐溶剤性に優れているが，長期 耐久性の面では劣化しやすく，耐候性や耐熱性の評価では，変色す

\section{Koichiro TAKAHASHI $-* 1 \quad$ Haruka OGAWA $-* 2$}

Organic reconstituted stone is often used as flooring of buildings in countries outside of Japan. As organic reconstituted stone contains polymer resin, it may discolor yellow by ultra-violet light and heat. At some construction sites, organic reconstituted stone became yellow. Authors conducted tests to investigate the causes of yellowing, methods of prevention and possibilities of further yellowing by replicating the process and making chemical analysis. They found out that long-term exposure to water and heat changes its chemical component and leads to the formation of chromophore having a conjugated double bond and auxochrome having a hydroxyl radical.
る傾向がある。これらに対してアクリル系人造大理石は強度面では ほぼ同等で，耐候性や耐熱性に優れ外観が変化しにくい。しかし， 非常に高価であるためキッチンの天板やバスタブなどの用途に限定 されている。

表 1 人造大理石の構成成分

\begin{tabular}{c|c|c}
\hline 素 材 & \multicolumn{1}{|c|}{ 成 分 } & 割 合 \\
\hline 樹 脂 & $\begin{array}{l}\text { 不飽和ポリエステル, スチレン, } \\
\text { 紫外線吸収剂 }\end{array}$ & 微 量 \\
\hline 添加物 1 & 反応促進剤, 触媒, シラン & 微 量 \\
\hline 添加物 2 & 骨材, フィラー, 顔料 & 多 量 \\
\hline
\end{tabular}

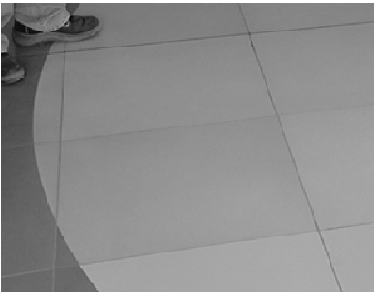

写真 1 全面型黄変

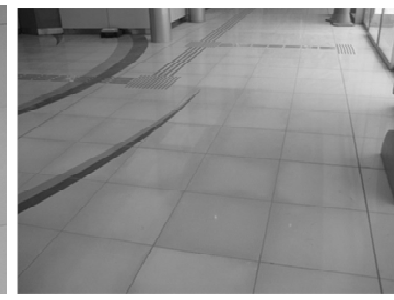

写真 2 額縁型黄変

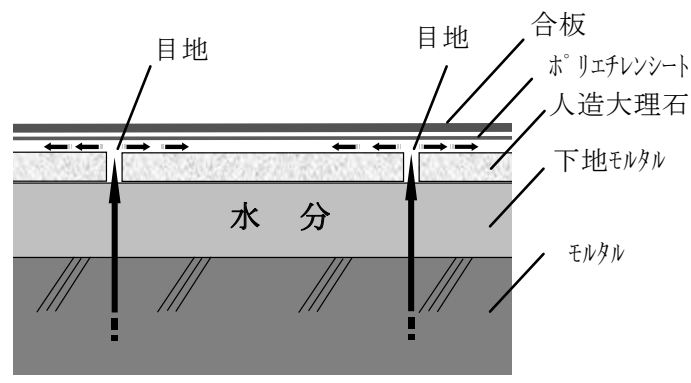

図 1 床の構成断面

\footnotetext{
(姝大林組技術研究所生産技術研究部 主任研究員

（广 204-0011 東京都清瀬市下清戸 4-640)

(烌)大林組技術研究所生産技術研究部 上級主席技師・博士（工学)
}

\footnotetext{
Section Manager, Technical Research Institute, Construction System and Materials Dept., Obayashi Corporation

2 Senior Engineer, Technical Research Institute, Construction System and Materials Dept., Obayashi Corporation, Dr. Eng.
} 


\section{2 人造大理石の組成}

黄変が発生した人造大理石は海外製の不飽和ポリエステル系人造 大理石であり，詳細な配合比などは公開されていないが，表 1 に主 な構成成分を示した。一般に国内で製造される不飽和ポリエステル 系人造大理石と比較して, 無機の骨材成分が非常に多く, 樹脂成分 は少ないのが特徵とされている。また, 弱点である紫外線による劣 化を防ぐため, 予め紫外線吸収剤が添加されている。

\section{3 人造大理石の黄変発生状況}

発生した黄変のパターンは大きく 2 種類に分けられる。写真 1 に 見られるような全面型黄変と写真 2 に見られるような額縁型黄変で ある。

\section{4 人造大理石の黄変発生原因の推定}

黄変が発生した床の構成断面を図 1 に示す。

ここでは, 人造大理石の施工後, 表面保護用の養生材（プラスチ ックシート, プラスチックベニア, 合板）が数ヶ月に亘り敷き詰め られていた。

養生材を撤去した時, 人造大理石と養生材との間は水で濡れてい た。黄変は工事中に下地モルタルやコンクリートなどに含まれてい た強アルカリ性の水分が目地部を介して表面に上昇し, 人造大理石 と養生材との間で結露し, 約 $40^{\circ} \mathrm{C}$ 以上の高温下で長期間接触して生 じたものと推定した。

\section{3. 促進劣化試験による黄変の再現}

\section{1 試験目的}

人造大理石に発生した黄変が 2.4 で推定した原因によるものかを 確認する目的で, 各種促進劣化試験による再現を試みた。

\section{2 試験計画}

\section{2.1 試験体 試験に用いた人造大理石の一覧を表 2 に示す。}

表 1 に示された顔料以外は, 各社共通の原料を用いる。試験には 未黄変の新しい人造大理石を使用した。

\subsection{2 試験方法人造大理石の黄変には「熱」「アルカリ性の水} 分」が影響したとの仮定より，これらの要因の影響が確認出来るよ うに試験を計画した。

\section{(1) 気中熱劣化試験}

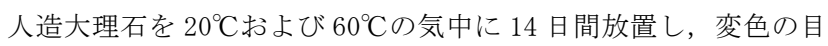
視観察ならびに b*(黄色度を表すクロマティックネス指数)の試験 前後の值を測定し，その変化量 $\Delta \mathrm{b} *$ を算出する。

（2）水中およびアルカリ水中（pH11～12）浸漬試験

人造大理石を $20^{\circ} \mathrm{C}$ おび $60^{\circ} \mathrm{C}$ の水中またはアルカリ水中 (セメン 卜上澄み液 $\mathrm{pH} 11 \sim 12 ） に 14$ 日間浸漬し, 変色の目視観察ならびに $\triangle \mathrm{b} *$ を行う。

表 2 試験に供した人造大理石一覧

\begin{tabular}{c|c|c}
\hline No. & 種類 (色) & 製造メーカー \\
\hline 1 & Luce Pura(白) & A 社 \\
\hline 2 & Virgo(白) & B 社 \\
\hline 3 & Luce Pura(白) & B 社 \\
\hline 4 & Virgo(白) & C 社 \\
\hline 5 & Luce Pura(白) & D 社 \\
\hline 6 & Luce Pura(白) & E 社 \\
\hline
\end{tabular}

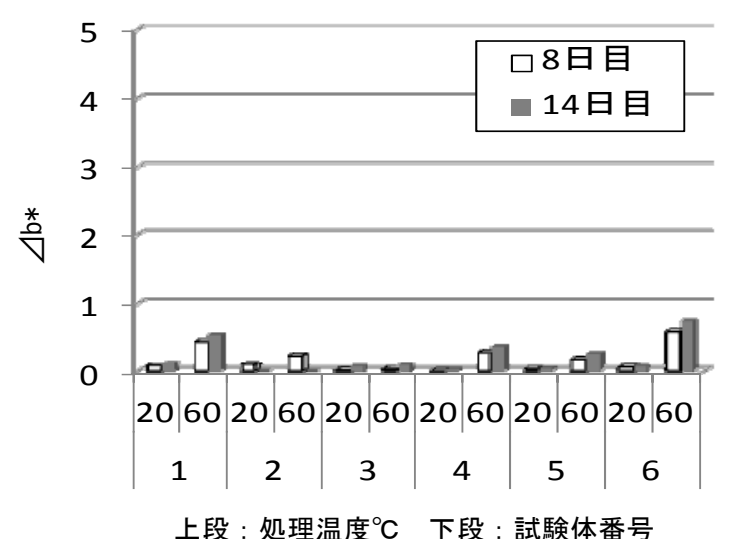

上段：処理温度 ${ }^{\circ} \mathrm{C}$ 下段: 試験体番号

図 2 気中熱劣化試験結果

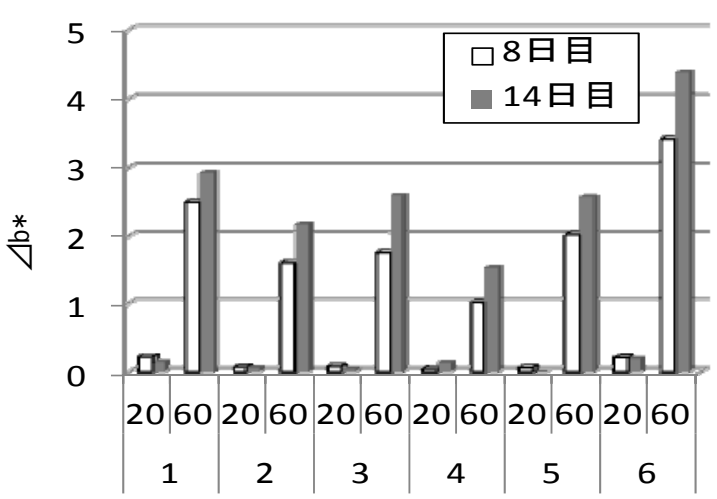

上段: 処理温度 ${ }^{\circ} \mathrm{C}$ 下段: 試験体番号

図 3 水中浸漬試験結果

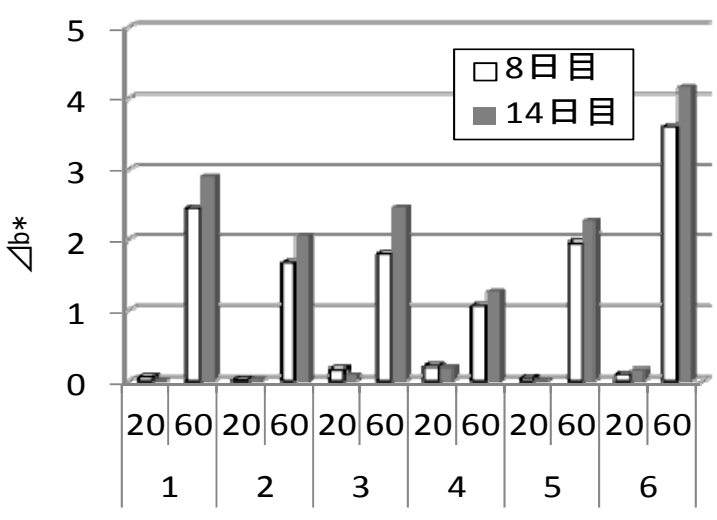

上段：処理温度 ${ }^{\circ} \mathrm{C}$ 下段: 試験体番号

図 4 アルカリ水中浸漬試験結果

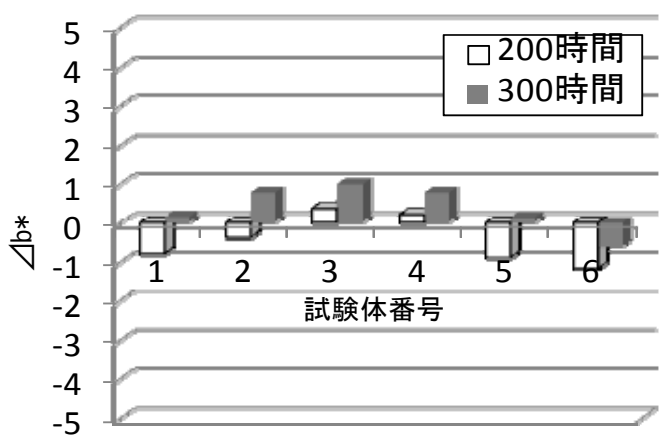

図 5 促進耐候性試験結果 


\section{（3）促進耐候性試験}

JIS K 7350-2（プラスチック一実験室光源による暴露試験方法一 第 2 部：キセノンアークランプ）（対応国際規格 IS04892-2）に準じ て，キセノンウェザーメータ（アトラス社製 Ci4000）を 2 時間（102 分光照射 $/ 18$ 分光照射十水スプレー) 1 サイクルとして，300 時間

（150 サイクル）まで稼働させ，人造大理石に発生する変色の有無 を目視観察ならびに黄色度の変化量 $\Delta \mathrm{b} *$ より評価する。

\section{3 評価方法}

黄変の度合いを数值化するため, 分光測色計（旧ミノルタ社製 CM-2002）にて bैを測定する。

測定点は 1 試験体について決められた 3 箇所の $\mathrm{b} * の$ 変化を測定し, その平均值で評価する。初期の $\mathrm{b}^{*} に$ 対して值が大きくなる（ $\Delta \mathrm{b} *>$

0）と黄色味が強くなることを示す。

\section{4 試験結果および考察}

3.4.1 熱, 水, アルカリ水の影響 図 2 に示すように気中にて 14 日間 $60^{\circ} \mathrm{C}$ で加熱した試験体は, $20^{\circ} \mathrm{C} て ゙$ 処理した場合と同様, $\Delta \mathrm{b} *$ は 1 以下であり目視でも黄変は確認されなかった。

これに対して, 図 3 , 図 4 に示寸ように $60^{\circ} \mathrm{C}$ の水やアルカリ水に 14 日間浸漬した全ての試験体において, $\Delta \mathrm{b} *$ は $1.5 \sim 4.3$ となり $20^{\circ} \mathrm{C}$ の場合と比べ顕著な差が見られ，目視観察でも黄変が確認できた。

また, 図 3 , 図 4 の結果より, アルカリ水の影響について, 水と の有意差は特に認められなかった。これらの結果から, 人造大理石 の黄変は熱と水が共存した条件下でのみ発生し, 樹脂部の加水分解 が熱により促進され生じた可能性が高いことが示唆された。

写真 1 , 写真 2 に見られる黄変パターンの違いは, 当初, 下地か らの水分が多い目地部から黄変は進行し, 徐々に全体に広がり、養 生期間の差により発生したのではないかと推定される。

3.4.2 紫外線の影響図 5 はキセノンウェザーメータによる促 進劣化後の $\Delta \mathrm{b} *$ 示したものである。200 時間を経過した時点で人 造大理石の $\Delta \mathrm{b} *$ は約 $-1.2 \sim 0.4,300$ 時間では約 $-0.6 \sim 1.0$, で, 目 視でも黄変は確認されなかった。そのため, 黄変の発生に紫外線の 影響を受けていないことが確認された。

\section{4. 化学分析による黄変発生メカニズムの推定 \\ 4. 1 試験目的}

黄変の再現試験により, 熱や水の劣化要因が素材中の化学組成に ぞのように影響を与え，黄変が発生することになったかを化学分析 により裏付けることを目的とする。

\section{2 試験計画}

\section{2.1 試験体実際に黄変が確認された人造大理石と未黄変の} もの（共にB 社 Luce Pura(白))を現場より入手し，分析に供した。

\section{2.2 試験方法}

(1) 表面観察

デジタルマイクロスコープ(キーエンス社製 VH-8000)により，黄 変した人造大理石の変色部位や変色の深さを断面方向から観察した。

（2）人造大理石中の構成元素之結晶性物質の確認

黄変および未黄変の人造大理石について樹脂部の構成元素に差が ないかを確認するため, EPMA（電子線マイクロアナライザー(島津製 作所社製 EPMA-1600))法により定性分析を行った。また, X線回折 法により人造大理石全体に含有する結晶性物質の定性分析を行った。

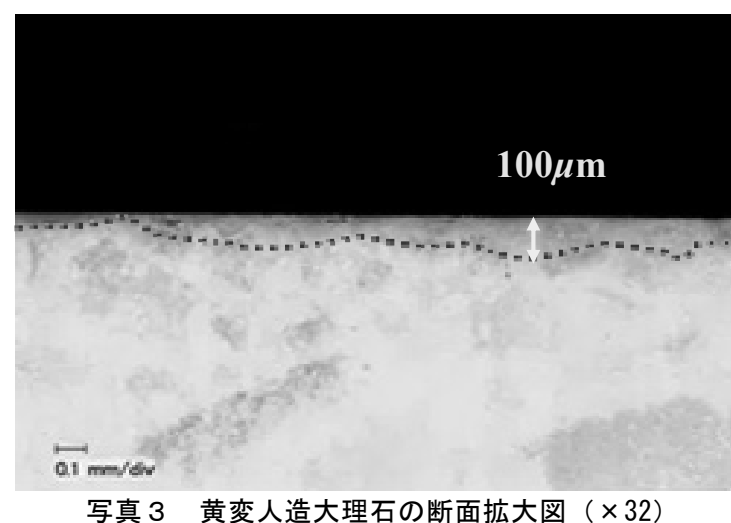

表 3 EPMA による人造大理石樹脂部の元素定性分析結果

\begin{tabular}{|c|c|c|}
\hline 相対量 & 黄変人造大理石 & 未黄変人造大理石 \\
\hline ++++ 非常に多い & - & - \\
\hline +++ 多い & Si, 0 & Si, 0 \\
\hline++ 中位 & $\mathrm{C}$ & C \\
\hline +＜wide>少ない & $\mathrm{Ti}$ & $\mathrm{Ti}$ \\
\hline (+) 非常に少ない & $\mathrm{Fe}, \mathrm{Ca}, \mathrm{Al}, \mathrm{K}, \mathrm{Na}, \mathrm{Mg}$ & $\mathrm{Fe}, \mathrm{Ca}, \mathrm{A} 1, \mathrm{~K}, \mathrm{Na}, \mathrm{Mg}$ \\
\hline
\end{tabular}

表 4 X 線回折による結晶性物質の定性分析結果

\begin{tabular}{c|c|c}
\hline \multirow{2}{*}{ 結晶性物質 } & \multicolumn{2}{|c}{ 相対量 } \\
\cline { 2 - 3 } & 黄変人造大理石 & 未黄変人造大理石 \\
\hline $\mathrm{SiO}_{2}$ & $++++($ 非常に多い) & $++++($ 非常に多い) \\
\hline $\begin{array}{c}\text { 石 英 } \\
\mathrm{TiO}_{2}\end{array}$ & ++ (中位 $)$ & ++ (中位 $)$ \\
\hline 酸化チ多 & + &
\end{tabular}

（3）人造大理石の樹脂部の化学構造分析

樹脂部について, 黄変を引き起こす化学構造の変化を調べるため FT-IR(フーリエ変換赤外分光光度計 (バイオ・ラッドラボラトリーズ社製 FTS-6000，UMA-500)により分析を行った。観察は試験体表面の付着 物の影響を除くため, 2-プロパノール (IPA) により洗浄し, 分析上 で障害となる試験体中の珪砂やフィラーの影響を避けるため，マイ クロサンプリング法にて樹脂部のみを採取して顕微透過法により観 察を行った。

\section{3 試験結果および考察}

4. 3. 1 黄変の発生状況写真 3 に示寸ように骨材自体には変色 が認められないものの樹脂部は, 表面から約 $100 \mu \mathrm{m}$ の深さまで黄変 し, 表面側ほど黄変が顕著であった。このことから, 黄変は樹脂部 の外部因子との接触により表面から生じていると推察した。

\section{3.2 人造大理石中の構成元素と結晶性物質の差異表 3 に} EPMA による樹脂部の構成元素を定性分析した結果を示す。両者の検 出元素および相対強度に差異は認められなかった。ただし, Fe (鉄) が微量検出されたことから錆による黄変も考えられたが，塩酸溶液 による処理 $\left(70^{\circ} \mathrm{C}, 17\right.$ 時間浸積 $)$ でも黄変の脱色が見られなかった ことより，錆が原因ではないことが確認された。 
表 4 は, X線回折法による人造大理石全体の結晶性物質の定性 分析を行った結果である。黄変人造大理石と未黄変のものの両者 に多量の石英および中量のルチル型酸化チタンが検出された。こ れらの結果より, 両者の検出元素および結晶性物質に有意差は認 められず，黄変の発生要因は検出されなかった。

4.3.3 黄変メカニズムの推定図 6 , 図 7 は, 黄変人造大理石 と未黄変人造大理石の FT-IR による分析結果である。波数 1,700 $\sim 1,500 \mathrm{~cm}^{-1}$ 付近と $3,400 \sim 3,100 \mathrm{~cm}^{-1}$ 付近の領域に見られる赤外 線吸収は, 黄変人造大理石の方が未黄変のものより強い。前者は 黄変の原因となる共役二重結合 $(\mathrm{C}=0, \mathrm{C}=\mathrm{C})$ の生成, 後者は水酸基 の生成を示唆する。二重結合の生成は, 人造大理石の表面からの 長期にわたる熱の供給が不飽和ポリエステルの化学構造を不安定 な状態とし, 分子の化学結合を変化させたものと考えられる。ま た, 水酸基は熱に加えて目地から上昇してきた下地モルタルやコ ンクリートからの湿気による加水分解により, 樹脂中に導入され 生成したものと推測される。共役二重結合と水酸基は, それぞれ 発色団と助色団と呼ばれ, 黄変はこれらが人造大理石の吸収スペ クトルの位置を移動させたり, 吸収強度を増大させることにより 発生したものと考えられる ${ }^{2)}{ }^{3)}$ 。黄変が表層 $100 \mu \mathrm{m}$ 程度までに 限定されているのは, 人造大理石は透湿抵抗が高く, 熱や湿気の 影響が極表層に限られたことによるものと推測される。

\section{5. 黄変の除去と再黄変性に関する検証 \\ 5.1 試験目的}

黄変が発生した人造大理石から黄変を除去するためには, 天然 石やプラスチックの漂白にも使用される過酸化水素希釈溶液によ り表面を湿布する方法と, グラインダーにて表面を研磨し物理的 に除去する方法が可能と考えられる。ここでは黄変の除去方法と 再黄変化の可能性を判定することを目的とする。

\section{2 試験内容}

5.2.1 試験体試験には, 現場より入手した人造大理石（B 社 Luce Pura (白)) より，未黄変(1), 黄変(2)，表層を過酸化水素 (30wt\% 溶液)にて 48 時間湿布漂白 (3) と, 表層黄変部を\#150, \#300, \#500, \# 1,000 の研磨ディスクによる 4 工程で, 浅め $(12 \mu \mathrm{m})$ (4), 普通 (14 $\mu \mathrm{m}$ ) (5), 深め (64 $\mu \mathrm{m})$ (6)に研磨した各種試験体を供した。

\subsection{2 試験方法自然光に近いとされるサンシャインウェザー} メータ（スガ試験機社製 WEL-SUN-DC）にて試験体に紫外線照射し， 再黄変の可能性を検証した。通常, サンシャインウェザーメータに よる促進耐侯性試験では水の噴霧も行われるが，人造大理石の使用 環境下においては水がないことを前提としているため紫外線のみを 720 時間照射した。

\section{3 評価方法}

再黄変の評価は, 目視観察と, 分光側色計 (旧ミノルタ社製 CM-2002）を用いた $b^{*}$ 值の測定により行った。

\section{4 試験結果および考察}

図 8 に 720 時間までの促進耐候性試験の結果を示す。この結果か ら, 表層を研磨した人造大理石は何れの研磨深さでも, 明らかに黄 変の進行が他の試験体に比べ遅く, 外観観察でも顕著な黄変の進行 は確認されなかった。これに対して当初から黄変していた人造大理

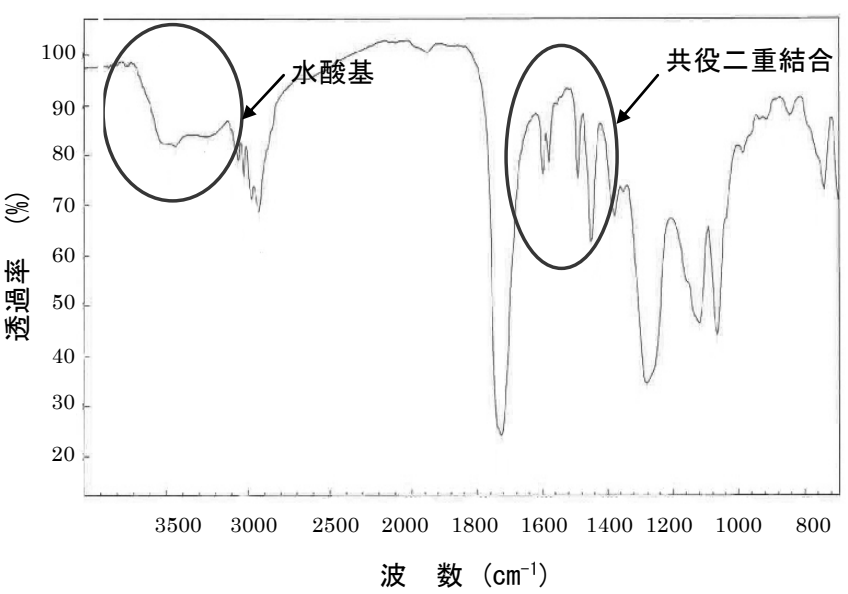

図 6 黄変人造大理石の FT-IR 分析結果

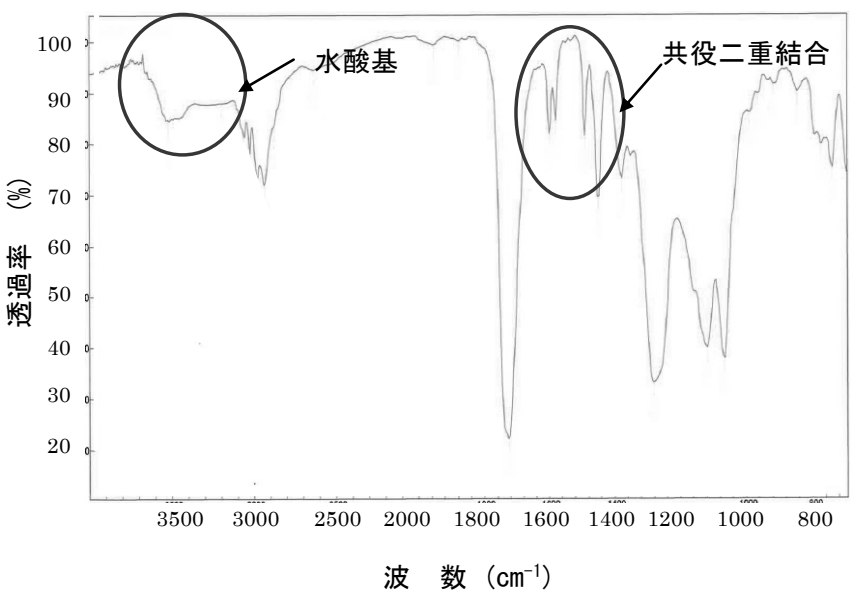

図 7 未黄変人造大理石の FT-IR 分析結果

石は更に黄変が進行した。過酸化水素 (30wt\%溶液) で脱色した人造大 理石も約 60 時間を経過した時点ですでに再黄変が見られ, その後も 黄変が進行した。未黄変だった人造大理石についても徐々に黄変化 が進行し, 試験開始後 420 時間経過しb*值が 12 を超えたころから 目視で黄変が確認出来るようになった。この值は現場にて黄変した と認識された人造大理石(1)の $\mathrm{b} *$ 值にほぼ等しい值であることから, 黄変の有無の判定基準を 12 とした。

\section{6. 再黄変の可能性予測}

\section{1 促進耐候性試験にもとづく再黄変予測}

黄変が発生した箇所の 1 年間の放射露光量は $7,500 \mathrm{MJ} / \mathrm{m}^{2}{ }^{4)}$, その うち 1 年間の紫外線領域 $(300 \sim 400 \mathrm{~nm})$ の放射露光量を構成比 $6.8 \%$ から換算すると $510 \mathrm{MJ} / \mathrm{m}^{2}$ となる。これをサンシャインウェザーメー タによる促進耐候性試験時間に換算すると、サンシャインウエザー メータから放射される $300 \sim 400 \mathrm{~nm}$ 領域の光の放射照度が $78.5 \mathrm{~W} / \mathrm{m}^{2}$ であることから，以下のように算出される。

510, 000, $000\left(\mathrm{~J} / \mathrm{m}^{2}\right) \div 78.5\left(\mathrm{~W} / \mathrm{n}^{2}\right)=6,796,000$ 秒（約 1, 890 時間）

よって, 今回実施した 720 時間の促進暴露試験は 0.3 ケ年 $($ 約 4.5 


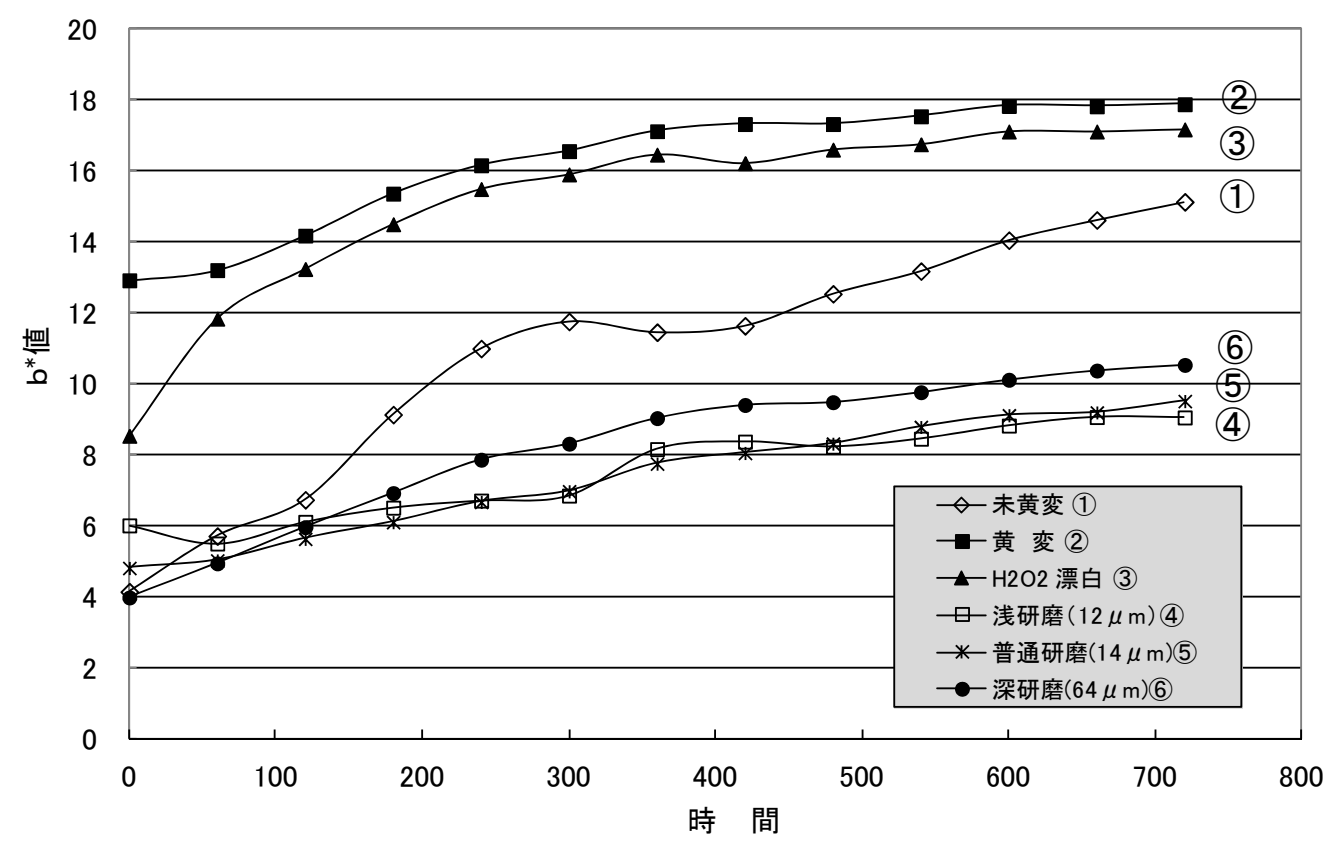

図 8 促進耐候性試験結果

ケ月)となる。しかし, 黄変が発生した䇢所の屋外と屋内の紫外線量 を紫外線センサーにて実測した結果, 屋外の紫外線量が $4,570 \mu$ $\mathrm{W} / \mathrm{cm}^{2}$ であったのに対し, 室内では $50 \mu \mathrm{W} / \mathrm{cm}^{2}$ 以下（多くの箇所はゼ ロに近い值)であり,室内紫外線量は屋外の約 $1 / 100$ 以下であった。 そのため, 0.38 ケ年を 100 倍すると 38 年相当となる。図 8 に示す ように, 過酸化水溶液で漂白した人造大理石は試験開始後約 60 時間 でb*值が 12 を越えたが，表面を研磨した人造大理石は 720 時間経 過してもb*值は 12 以下であり, 計算上 38 年を経過しても顕著な黄 変は生じないものと考えられる。また, 未黄変の人造大理石も約 420 時間までは $b *$ 值は 12 以下であるため, 同様に換算すると約 22 年は 顕著な変色は発生しないものと予測できる。

\section{2 分析にもとづく再黄変予測}

4.3 に述べたように, 黄変は断面の観察から深いところでも 100 $\mu \mathrm{m}$ 以下であり, 人造大理石の極表層に限られていた。また, 3.6 の促進試験による黄変の再現結果より, 当初の黄变発生要因は水と 熱が要因であり, 4.3 に示した FT-IR による分析結果より, 黄変に は発色団（共役二重結合）と助色団（水酸基）の生成が関与してい ると推定された。そのため, この発色団を含む表層部分を研磨除去 すれば，養生時のように人造大理石の表面が再度水と熱に長期間曝 されるような環境にならない限り，今回のような短期間での再黄変 はしないものと推定される。このような推定結果は, 5.4 で示した サンシャインウェザーメータによる促進暴露試験からも，表面研磨 した試験体については他の試験体に比べ変色の速度は非常に遅く, 試験開始後 720 時間（実暴露換算 38 年相当）を経過しても，目視で は顕著な黄変として確認できなかったことからも裏付けられる。ま た, 未黄変人造大理石が表面研磨したものと比較して黄変の進行が 早かった原因は, 前者の発足団と助色団の量は FT-IR による分析結 果より後者より少なかったが, 僅かに表層部には存在し, 紫外線を 受けることでそれらの生成が促進されたとによると推定される。

\section{7. まとめ}

有機系高分子材料の黄変は紫外線が要因であることが一般的であ るが，今回のように紫外線が殆ど当たらない場所で発生することは 稀である。黄変が発生した箇所の環境を再現した促進劣化試験では, 人造大理石上に透湿抵抗の高い養生材が敷かれ，その表面が長期間 高温多湿な状態に曝されていたことが原因で黄変が発生したことが 明らかとなった。また，化学分析では，熱と水が人造大理石中の極 微量な樹脂部の加水分解を促進し, 共役二重結合を有する発色団と, 水酸基を有する助色団を生成させたことに因るもので，極表面に限 定されることが明らかとなった。発生した黄変の除去には過酸化水 素の希釈溶液による湿布は一時的な漂白は可能であるが，短期間で 黄変が再発することが実験により検証され, 表層の黄変部を研磨し て取り除く方法であれば，再黄変しないことが明らかとなった。人 造大理石に限らず有機系素材の変色などの劣化現象は非常に䋊細か つ複雑であり，保管時や施工・養生時には高温多湿な環境に曝さな いようにするなど取り扱いには十分配慮する必要がある。また劣化 の早期予測手法の確立も今後の重要な課題と考えられる。

\section{参考文献}

1）三浦勇雄他: 建築用石材の変質現象 鉱物学的な検討と早期変質判定方法, 戸田建設技術研究報告，No.26 pp.65～74，2000.3

2）山野井博：高分子材料の劣化・変色メカニズムと安定化技術，マテリア ルライフ学会誌，19，pp.103〜108，2007.7

3）大武義人: ゴム・プラスチック材料のトラブルと対策, 日刊工業社, 2009.6

4） JIS D 0205, 自動車部品の耐候性試験方法，P. 解 4, 1987

[2013 年 2 月 14 日原稿受理 2013 年 4 月 11 日採用決定 $]$ 